Supporting Information for

\title{
A lysosome-targeted turn-on fluorescent probe for endogenous formaldehyde in living cells
}

\author{
Yonghe Tang, ${ }^{\ddagger}$ Xiuqi Kong, ${ }^{\ddagger}$ Zhan-Rong Liu, An Xu, and Weiying Lin* \\ Institute of Fluorescent Probes for Biological Imaging, School of Chemistry and \\ Chemical Engineering, School of Biological Science and Technology, University of \\ Jinan, Jinan, Shandong 250022, P. R. China. \\ E-mail: weiyinglin2013@163.com
}




\section{Table of Content}

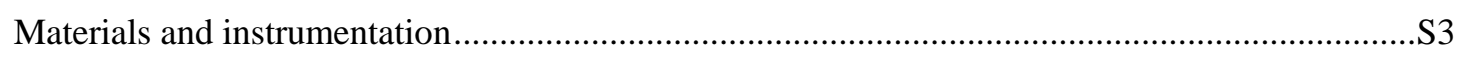

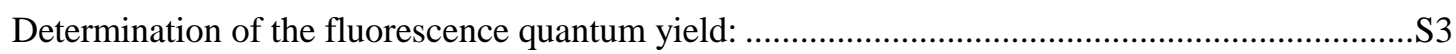

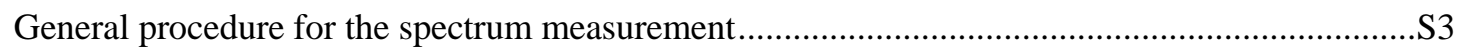

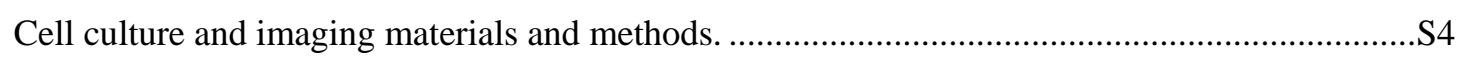

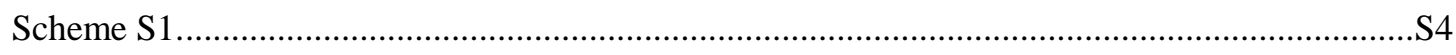

Synthesis of N-(2-morpholinoethyl)-4-bromo-naphthalimide 1 ..................................................S5

Synthesis of N-(2-morpholinoethyl)-4-hydrazino-naphthalimide Na-FA-Lyso.............................S5

Synthesis of the product of the probe with FA (the compound 2) ............................................... 6

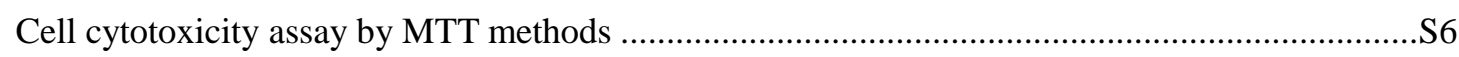

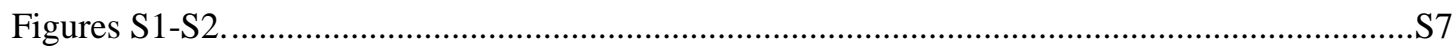

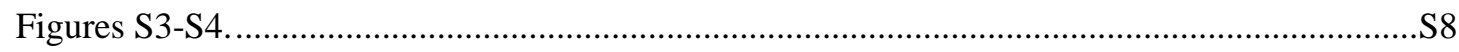

Figure S5 .

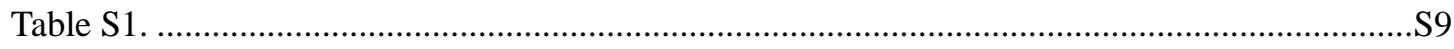

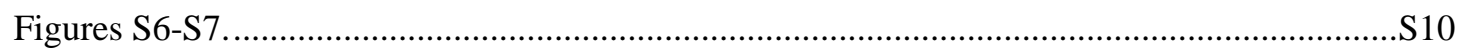

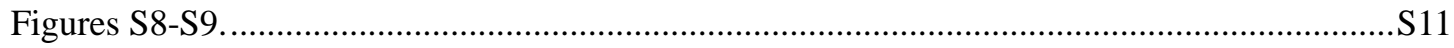

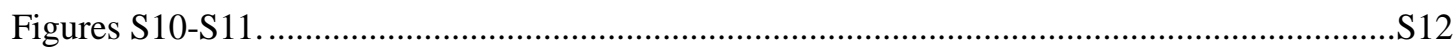

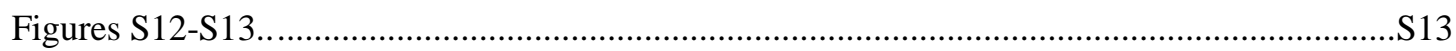

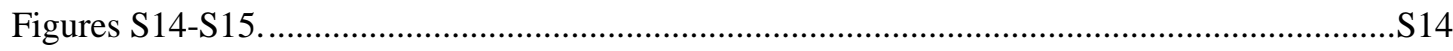

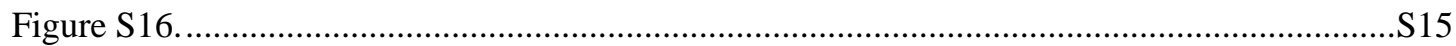




\section{Materials and instrumentation}

Unless otherwise stated, all solvents and reagents were commercially available and used without further purification. Solvents used were purified by standard methods prior to use. Doubly distilled water was used throughout all experiments. Thin-layer chromatography (TLC) analysis was performed on silica gel plates and column chromatography was conducted over silica gel (mesh 200-300), both of which were obtained from the Qingdao Ocean Chemicals. MTT (3-(4, 5-Dimethylthiazol-2-yl)-2,5-diphenyltetrazolium bromide) was from Sigma. LysoTracker Deep Red was purchased from Life Technologies. High-resolution mass spectra (HRMS) were recorded on a Bruker Apex Ultra 7.0 T FTMS mass spectrometer in electrospray ionization (ESI) mode. The ${ }^{1} \mathrm{H}$ NMR and ${ }^{13} \mathrm{C} N M R$ spectra were recorded on a Bruker AVANCE III $400 \mathrm{MHz}$ Digital NMR Spectrometer, and using DMSO- $d_{6}$ as solvent and tetramethylsilane (TMS) as internal reference respectively. UV-vis absorption spectra were recorded on a Shimadzu UV-2600 UV-vis spectrophotometer and fluorescent spectra were measured on a Hitachi F-4600 luminescence spectrophotometer with a $1 \mathrm{~cm}$ standard quartz cell. The fluorescence imaging of cells was performed using a Nikon A1MP confocal microscope. The $\mathrm{pH}$ measurements were carried out on a Mettler-Toledo Delta $320 \mathrm{pH}$ meter.

\section{Determination of the fluorescence quantum yield:}

The fluorescence quantum yields $(\Phi)$ were calculated by equation (1):

$$
\Phi_{\mathrm{s}}=\Phi_{\mathrm{r}}\left(\mathrm{n}_{\mathrm{s}} / \mathrm{n}_{\mathrm{r}}\right)^{2}\left(\mathrm{~A}_{\mathrm{r}} / \mathrm{A}_{\mathrm{s}}\right)\left(\mathrm{F}_{\mathrm{S}} / \mathrm{F}_{\mathrm{r}}\right)
$$

In equation, $A_{s}$ and $A_{r}$ are the absorbance of the sample and the reference, respectively, at the same excitation wavelength, $F_{s}$ and $F_{r}$ are the corresponding relative integrated fluorescence intensities, and $\mathrm{n}$ is the refractive index of the solvent. $\Phi$ was quantum yield.

\section{General procedure for the spectrum measurement}

The stock solution of the probe Na-FA-Lyso was prepared at $1 \mathrm{mM}$ in DMSO. The solutions of the various testing species were prepared from the representative amino acids, $\mathrm{Na}_{2} \mathrm{SO}_{3}, \mathrm{NaNO}_{2}, \mathrm{MgCl}_{2}, \mathrm{KNO}_{3}, \mathrm{H}_{2} \mathrm{O}_{2}, \mathrm{NaClO}, \mathrm{CaCl}_{2}, \mathrm{Na}_{2} \mathrm{~S}, \mathrm{NaHSO}_{3}$, $\mathrm{NO}$, and tert-Butyl hydroperoxide in the doubly distilled water, and ketones and aldehydes in the DMSO. The test solution of the probe Na-FA-Lyso $(5.0 \mu \mathrm{M})$ in 10 $\mathrm{mM}$ PBS buffer ( $\mathrm{pH}$ 7.4) with $1 \%$ DMSO was prepared by placing the probe Na-FA-Lyso stock solution and DMSO in PBS buffer. The resulting solution was shaken well and incubated with the appropriate testing species before recording the spectra. Unless otherwise noted, for all the measurements, the excitation wavelength was $440 \mathrm{~nm}$, the excitation slit widths were $5 \mathrm{~nm}$, and the emission slit widths were 5 nm. 


\section{Cell culture and imaging materials and methods.}

HeLa cells were cultured in Dulbecco's Modified Eagle Medium media (DMEM, Hyclone) supplemented with $10 \%$ heat-inactivated fetal bovine serum (FBS, Sijiqing) and $1 \%$ antibiotics (100 U/mL penicillin and $100 \mu \mathrm{g} / \mathrm{mL}$ streptomycin, Hyclone) at $37{ }^{\circ} \mathrm{C}$ and $5 \% \mathrm{CO}_{2}$. Before the imaging experiments, $1 \mathrm{~mL}$ of HeLa cells were subcultured and seeded in the glass bottom culture dishes (Nest) at a density of $1 \times 10^{5}$. The next day, the cells reached about $70 \%$ confluence for the further experiments.

For the fluorescence imaging studies of added FA in the living HeLa cells, we performed two sets of control experiments: the HeLa cells in the culture medium; the HeLa cells were incubated with $50 \mu \mathrm{M}$ FA in the culture medium for $30 \mathrm{~min}$. For the experimental group, the culture medium of the cells was changed to a fresh media containing $5 \mu \mathrm{M}$ probe and further incubated for $30 \mathrm{~min}$. Then, the medium was removed and washed three times with PBS to remove the excess probe. After that, $1 \mathrm{~mL}$ of the culture medium containing $50 \mu \mathrm{M}$ FA was added to the cells, and then incubated for $30 \mathrm{~min}$. The residual FA was removed by washing three times using PBS before the imaging by a Nikon A1MP fluorescence microscope equipped with $40 \times$ objective lens. For detecting fluorescence imaging, the excited wavelength was set at $488 \mathrm{~nm}$, and emission wavelengths were collected from $500 \mathrm{~nm}$ to $550 \mathrm{~nm}$.

For the fluorescence imaging experiment of the endogenous FA in the living HeLa cells, we first conducted a control experiment, in which the HeLa cells were incubated with $200 \mu \mathrm{M} \mathrm{NaHSO}_{3}$ for $30 \mathrm{~min}$. For the experimental group, the culture medium of the cells was changed to a fresh media with $5 \mu \mathrm{M}$ probe, and then incubated for 30 min. Subsequently, the medium was removed and washed three times with PBS to remove the excess probe. Furthermore, we carried out the negative control experiment, in which the culture medium of the cells was changed to a fresh medium with $200 \mu \mathrm{M}$ $\mathrm{NaHSO}_{3}$, and then incubated for $30 \mathrm{~min}$. Then, the medium was removed and washed three times with PBS to remove the excess $\mathrm{NaHSO}_{3}$. After that, $1 \mathrm{~mL}$ of the medium containing $5 \mu \mathrm{M}$ probe was added and then incubated for $30 \mathrm{~min}$. The residual probe was washed three times before the imaging by a Nikon A1MP fluorescence microscope equipped with $40 \times$ objective lens. For detecting fluorescence imaging, the excited wavelength was set at $488 \mathrm{~nm}$, and emission wavelengths were collected from $500 \mathrm{~nm}$ to $550 \mathrm{~nm}$.

Scheme S1. Synthesis of the fluorescent formaldehyde probe Na-FA-Lyso.

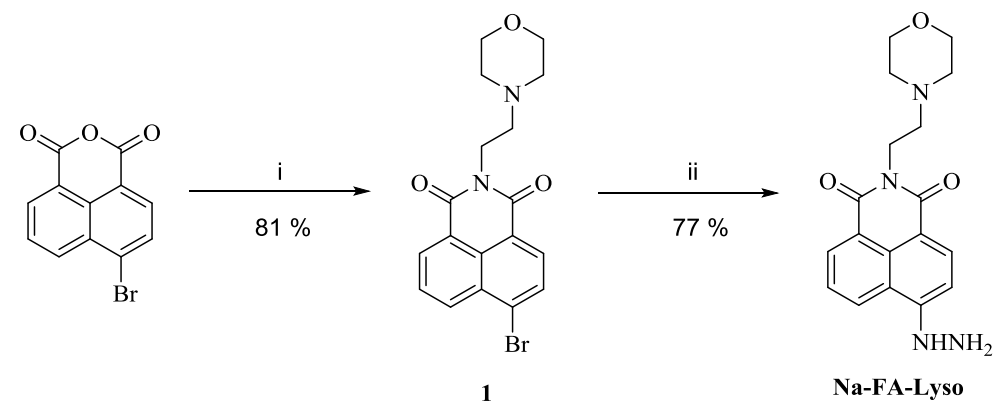

Reagents and conditions: (i) 4-(2-Aminoethyl)morpholine, ethanol, reflux, 2h; (ii) Hydrazine hydrate, ethanol, reflux, $4 \mathrm{~h}$. 


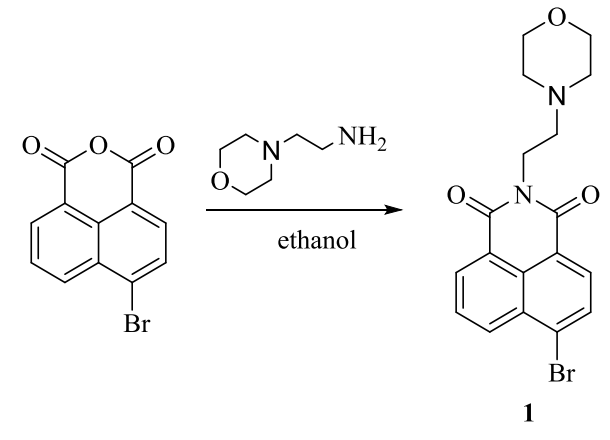

4-Bromo-1,8-naphthalic anhydride $277 \mathrm{mg}(1 \mathrm{mmol})$ and 4-(2-Aminoethyl)morpholine $169 \mathrm{mg}(1.3 \mathrm{mmol})$ were added to $2 \mathrm{~mL}$ of ethanol, and the reaction mixture was heated to reflux. After $2 \mathrm{~h}$, the mixture was cooled to room temperature, filtered, and dried to afford the desired product as a gray solid $315 \mathrm{mg}$ with a yield of $81 \% .{ }^{1} \mathrm{H}$ NMR (400 MHz, DMSO- $\left.d_{6}\right) \delta 8.50\left(\mathrm{dd}, J_{l}=7.2 \mathrm{~Hz}, J_{2}=0.8 \mathrm{~Hz}, 1 \mathrm{H}\right), 8.44$ $(\mathrm{d}, J=8.8 \mathrm{~Hz}, 1 \mathrm{H}), 8.24(\mathrm{~d}, J=7.6 \mathrm{~Hz}, 1 \mathrm{H}), 8.13(\mathrm{~d}, J=7.6 \mathrm{~Hz}, 1 \mathrm{H}), 7.92\left(\mathrm{dd}, J_{l}=\right.$ $\left.8.4 \mathrm{~Hz}, J_{2}=7.2 \mathrm{~Hz}, 1 \mathrm{H}\right), 4.14(\mathrm{t}, J=7.2 \mathrm{~Hz}, 2 \mathrm{H}), 3.54(\mathrm{t}, J=4.4 \mathrm{~Hz}, 4 \mathrm{H}), 2.56(\mathrm{t}, J=$ $7.2 \mathrm{~Hz}, 2 \mathrm{H}), 2.47(\mathrm{~s}, 4 \mathrm{H}) ;{ }^{13} \mathrm{C}$ NMR (100 MHz, DMSO- $\left.d_{6}\right) \delta 162.91,162.86,132.70$, 131.67, 131.43, 131.05, 129.86, 129.19, 128.88, 128.35, 122.77, 121.99, 66.25, 55.48, 53.42, 36.97; HR-MS calculated for $\mathrm{C}_{18} \mathrm{H}_{17} \mathrm{BrN}_{2} \mathrm{O}_{3}[\mathrm{M}+\mathrm{H}]^{+} \mathrm{m} / \mathrm{z}$ 389.0495, found 389.0490 .

Synthesis of N-(2-morpholinoethyl)-4-hydrazino-naphthalimide Na-FA-Lyso.
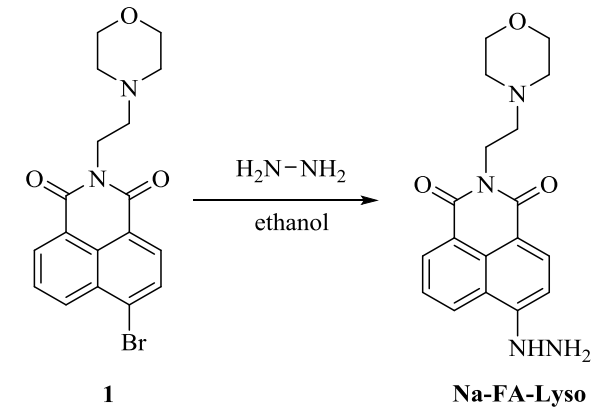

A mixture of compound $178 \mathrm{mg}(0.2 \mathrm{mmol})$ and $0.3 \mathrm{~mL} 80 \%$ hydrazine hydrate in $2 \mathrm{~mL}$ ethanol was heated under reflux for $4 \mathrm{~h}$. After cooling to room temperature, the precipitated product was filtered, washed with cold-EtOH, and the crude product was purified by flash chromatography on silica gel $(\mathrm{DCM} / \mathrm{MeOH}=30: 1)$ and re-crystallized from EtOH to afford an orange solid Na-FA-Lyso $52 \mathrm{mg}$ with a yield of $77 \% .{ }^{1} \mathrm{H}$ NMR $\left(400 \mathrm{MHz}, \mathrm{DMSO}-d_{6}\right) \delta 9.14(\mathrm{~s}, 1 \mathrm{H}), 8.60(\mathrm{~d}, J=8.0 \mathrm{~Hz}, 1 \mathrm{H}), 8.40$ $(\mathrm{d}, J=8.0 \mathrm{~Hz}, 1 \mathrm{H}), 8.28(\mathrm{~d}, J=8.0 \mathrm{~Hz}, 1 \mathrm{H}), 7.63(\mathrm{t}, J=8.0 \mathrm{~Hz}, 1 \mathrm{H}), 7.24(\mathrm{~d}, J=8.0$ $\mathrm{Hz}, 1 \mathrm{H}), 4.69$ (s, 2H), 4.14 (t, $J=8.0 \mathrm{~Hz}, 2 \mathrm{H}), 3.54$ (t, $J=4.0 \mathrm{~Hz}, 4 \mathrm{H}), 2.53$ (t, $J=8.0$ $\mathrm{Hz}, 2 \mathrm{H}), 2.46(\mathrm{~s}, 4 \mathrm{H}) ;{ }^{13} \mathrm{C}$ NMR $\left(100 \mathrm{MHz}, \mathrm{DMSO}-d_{6}\right) \delta 164.21,163.31,153.65$, 134.66, 131.01, 129.74, 128.70, 124.52, 122.09, 118.84, 107.72, 104.42, 66.67, 56.28, 53.89, 36.81; HR-MS calculated for $\mathrm{C}_{18} \mathrm{H}_{21} \mathrm{~N}_{4} \mathrm{O}_{3}[\mathrm{M}+\mathrm{H}]^{+} \mathrm{m} / \mathrm{z}$ 341.1608, found 341.1612 . 
Synthesis of the product of the probe with FA (the compound 2).
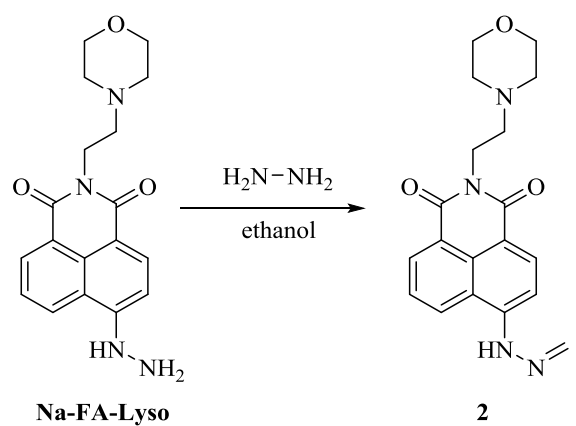

The compound Na-FA-Lyso (68 mg, $0.2 \mathrm{mmol}$ ) was dissolved in $95 \%$ ethanol $(1 \mathrm{~mL})$, and then FA (375 mg, $1 \mathrm{mmol}, 40 \%$ solution in $\mathrm{H}_{2} \mathrm{O}$ ) was added. The suspension was stirred at room temperature for $15 \mathrm{~min}$. Subsequently, the mixture was concentrated under vacuum, and the resulting residue was purified by silica gel column chromatography $(\mathrm{DCM} / \mathrm{MeOH}=20: 1$ to $10: 1)$ to afford an orange solid 49 mg with a yield of $70 \% .{ }^{1} \mathrm{H}$ NMR (400 MHz, DMSO- $\left.d_{6}\right) \delta 11.27(\mathrm{~s}, 1 \mathrm{H}), 8.70(\mathrm{~d}, J=$ $8.4 \mathrm{~Hz}, 1 \mathrm{H}), 8.45(\mathrm{~d}, J=6.4 \mathrm{~Hz}, 1 \mathrm{H}), 8.32(\mathrm{~d}, J=8.4 \mathrm{~Hz}, 1 \mathrm{H}), 7.75\left(\mathrm{dd}, J_{1}=8.4 \mathrm{~Hz}\right.$, $\left.J_{2}=7.6 \mathrm{~Hz}, 1 \mathrm{H}\right), 7.53(\mathrm{~d}, J=8.4 \mathrm{~Hz}, 1 \mathrm{H}), 7.39(\mathrm{~d}, J=12.0 \mathrm{~Hz}, 1 \mathrm{H}), 6.68(\mathrm{~d}, J=12.0$ $\mathrm{Hz}, 1 \mathrm{H}), 4.14(\mathrm{t}, J=6.8 \mathrm{~Hz}, 2 \mathrm{H}), 3.54(\mathrm{t}, J=4.4 \mathrm{~Hz}, 4 \mathrm{H}), 2.53(\mathrm{t}, J=7.2 \mathrm{~Hz}, 2 \mathrm{H})$, $2.46(\mathrm{~s}, 4 \mathrm{H}) .{ }^{13} \mathrm{C}$ NMR $\left(100 \mathrm{MHz}, \mathrm{DMSO}-d_{6}\right) \delta 164.03,163.31,147.13,135.68$, 133.84, 131.25, 129.45, 128.71, 125.31, 122.31, 118.70, 111.46, 107.05, 66.68, 56.16, 53.88, 36.94. HR-MS calculated for $\mathrm{C}_{19} \mathrm{H}_{21} \mathrm{~N}_{4} \mathrm{O}_{3}[\mathrm{M}+\mathrm{H}]^{+} \mathrm{m} / \mathrm{z} 353.1608$, found 353.1612 .

\section{Cell cytotoxicity assay by MTT methods}

$1 \times 10^{4} \mathrm{HeLa}$ cells were seeded into a 96 -well plate. The next day the medium was changed into a medium containing a series of concentrations of the probe $(1,5$, $10,20$ and $50 \mu \mathrm{M})$. After $24 \mathrm{~h}, 10 \mu \mathrm{L}$ of MTT ( $5 \mathrm{mg} / \mathrm{mL}$ in PBS) was added and incubated for $4 \mathrm{~h}$. Then, the culture medium was removed, and $100 \mu \mathrm{L}$ DMSO was added into the dishes to dissolve the formazan crystal product. The plate was shaken for $10 \mathrm{~min}$, and then absorbance at $570 \mathrm{~nm}$ was measured by the microplate reader. The cell viability (\%) was calculated by equation (2):

The cell viability $(\%)=\left(\mathrm{OD}_{570 \text { sample }}-\mathrm{OD}_{570 \text { blank }}\right) /\left(\mathrm{OD}_{570 \text { control}}-\mathrm{OD}_{570 \text { blank }}\right) \times 100 \%$.

In equation, $\mathrm{OD}_{570}$ sample denotes the cells incubated with various of concentrations of the probe, $\mathrm{OD}_{570 \text { control }}$ denotes the cells without the probe, $\mathrm{OD}_{570}$ blank denotes the wells containing only the culture medium. 
Absorption spectrum of the probe Na-FA-Lyso: The absorption profile of compound Na-FA-Lyso in $10 \mathrm{mM}$ PBS buffer (pH 7.4, 1 \% DMSO) is shown in Figure $\mathrm{S} 1$. The probe displays a maximal absorption at around $440 \mathrm{~nm}(\varepsilon=26,800$ $\mathrm{M}^{-1} \mathrm{~cm}^{-1}$ ) in $10 \mathrm{mM}$ PBS buffer (pH 7.4, $1 \%$ DMSO).

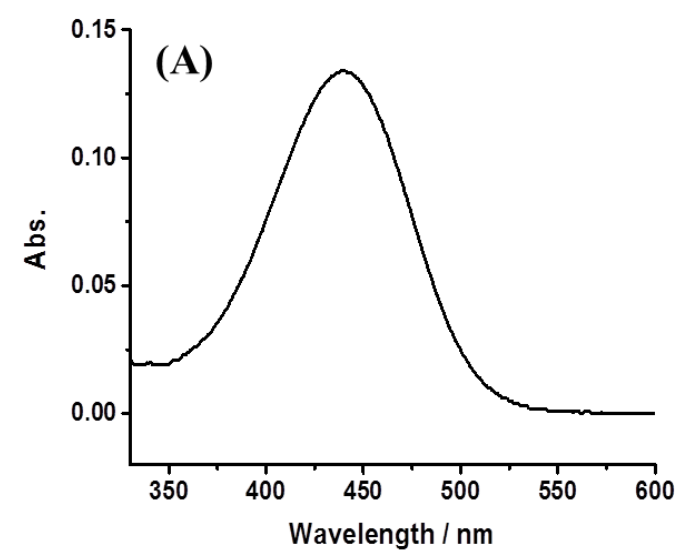

Figure S1. Absorption spectrum of the probe Na-FA-Lyso $(5 \mu \mathrm{M})$ in $10 \mathrm{mM}$ PBS buffer (pH 7.4, $1 \%$ DMSO).

Detection limit: The detection limit was determined from the fluorescence titration data based on a reported method. ${ }^{1}$ The probe Na-FA-Lyso $(5 \mu \mathrm{M})$ was titrated with FA $(0-200 \mu \mathrm{M})$ for $30 \mathrm{~min}$. The fluorescent intensity data at $543 \mathrm{~nm}$ were normalized between the minimum intensity and the maximum intensity. A linear regression curve was then fitted to the normalized fluorescent intensity data and the point at which this line crossed the axis was considered as the detection limit $\left(5.02 \times 10^{-6} \mathrm{M}\right)$.

${ }^{1}$ Shortreed M.; Kopelman R.; Kuhn M.; Hoyland B.; Anal. Chem., 1996, 68, 1414-1418.

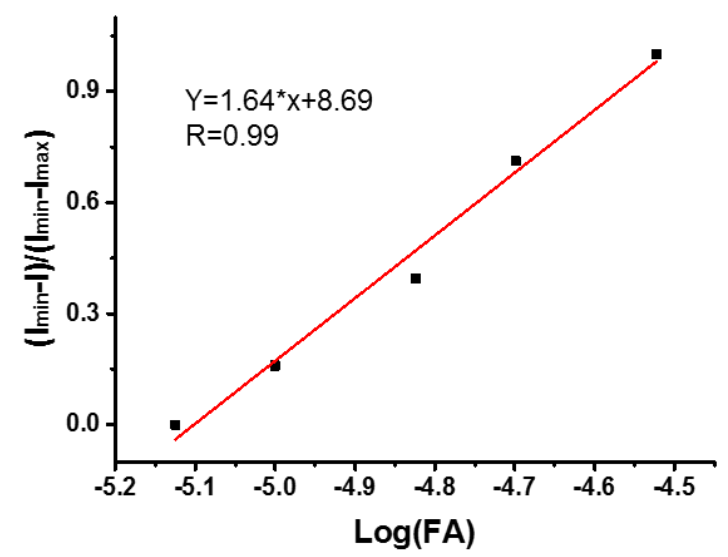

Figure S2. Normalized response of the fluorescence signal by changing the concentration of FA. 


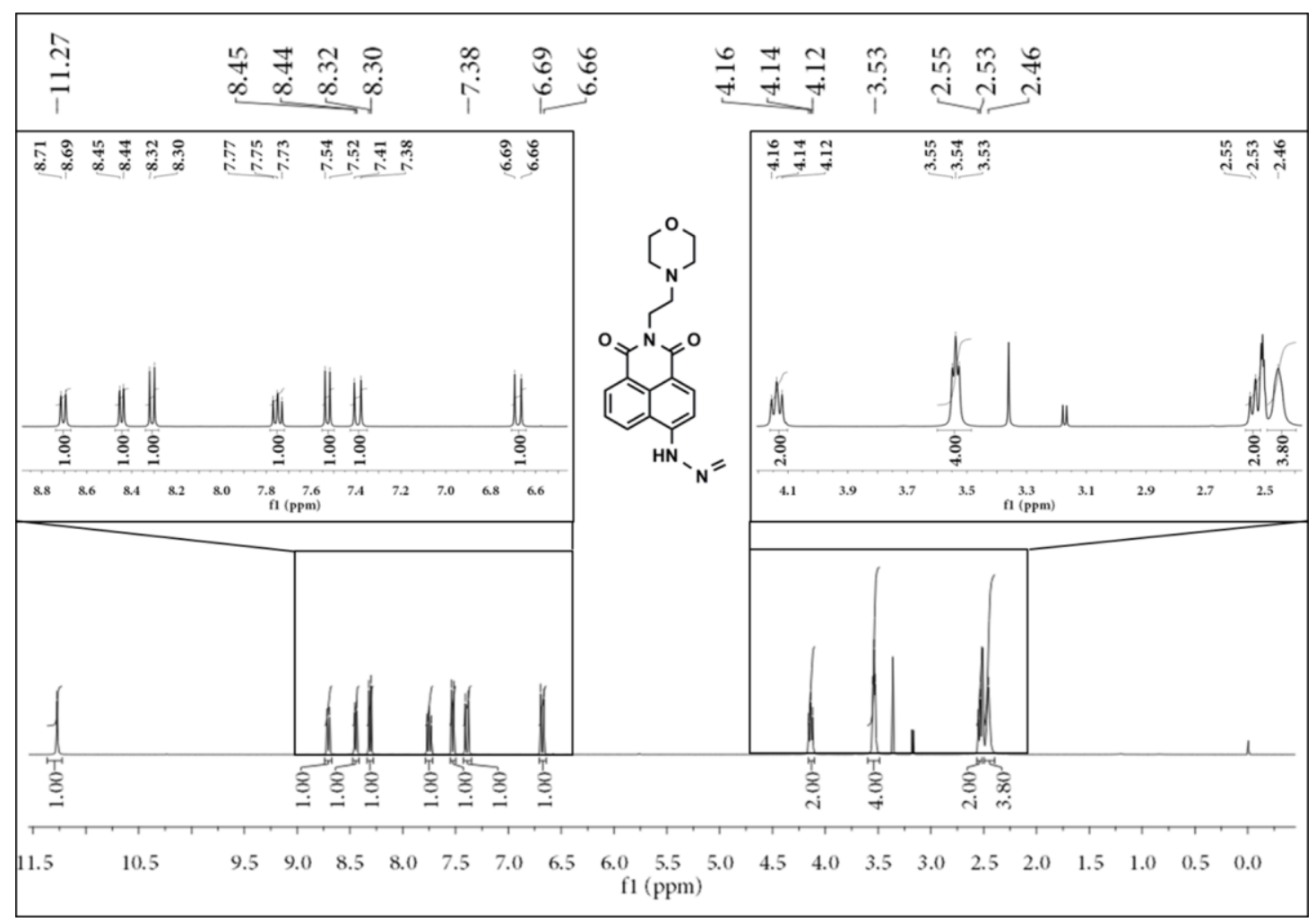

Figure S3. ${ }^{1} \mathrm{H}$ NMR spectrum of the product (the compound 2) of the probe with FA.

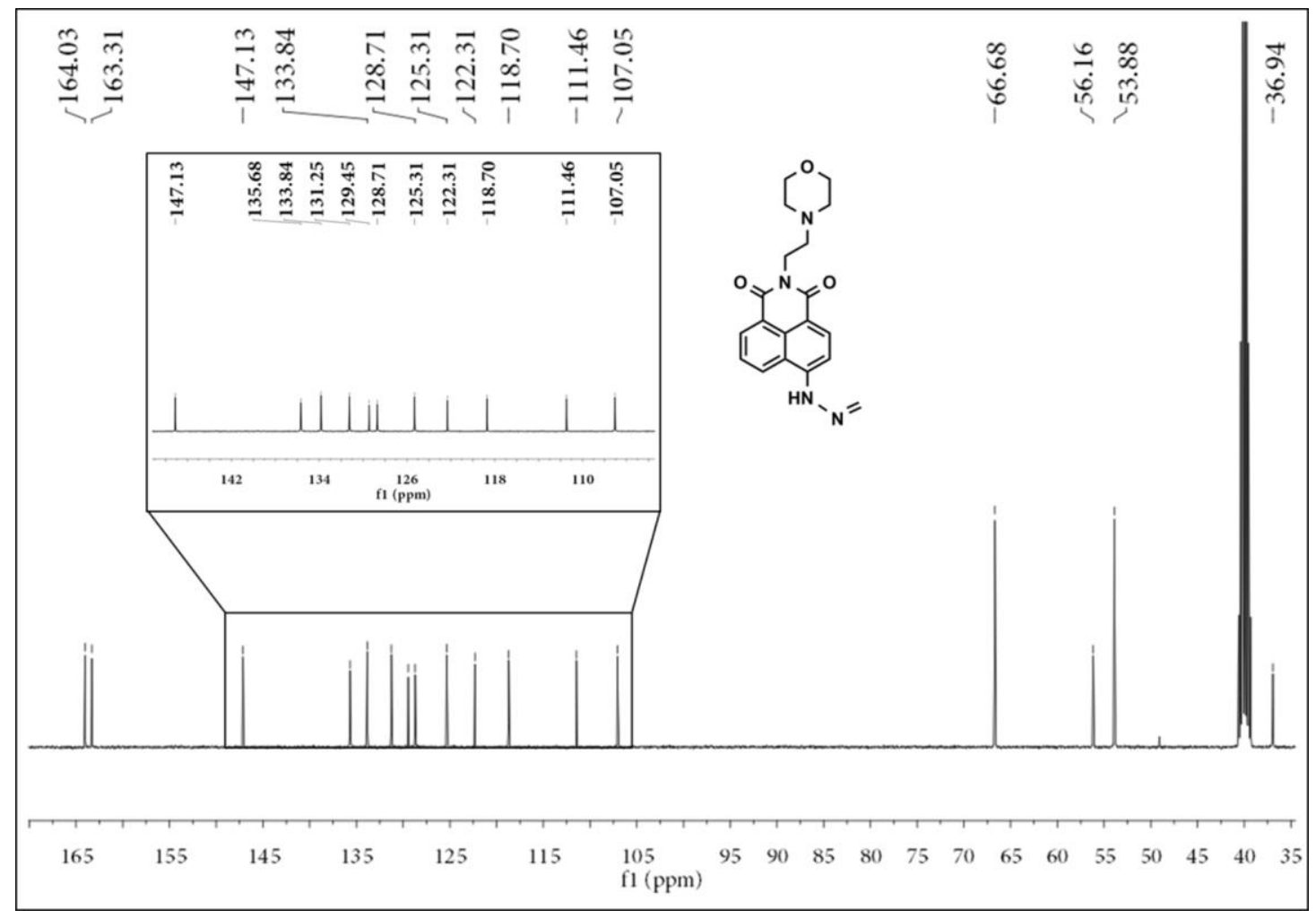

Figure S4. ${ }^{13} \mathrm{C}$ NMR spectrum of the product (the compound 2) of the probe with FA. 


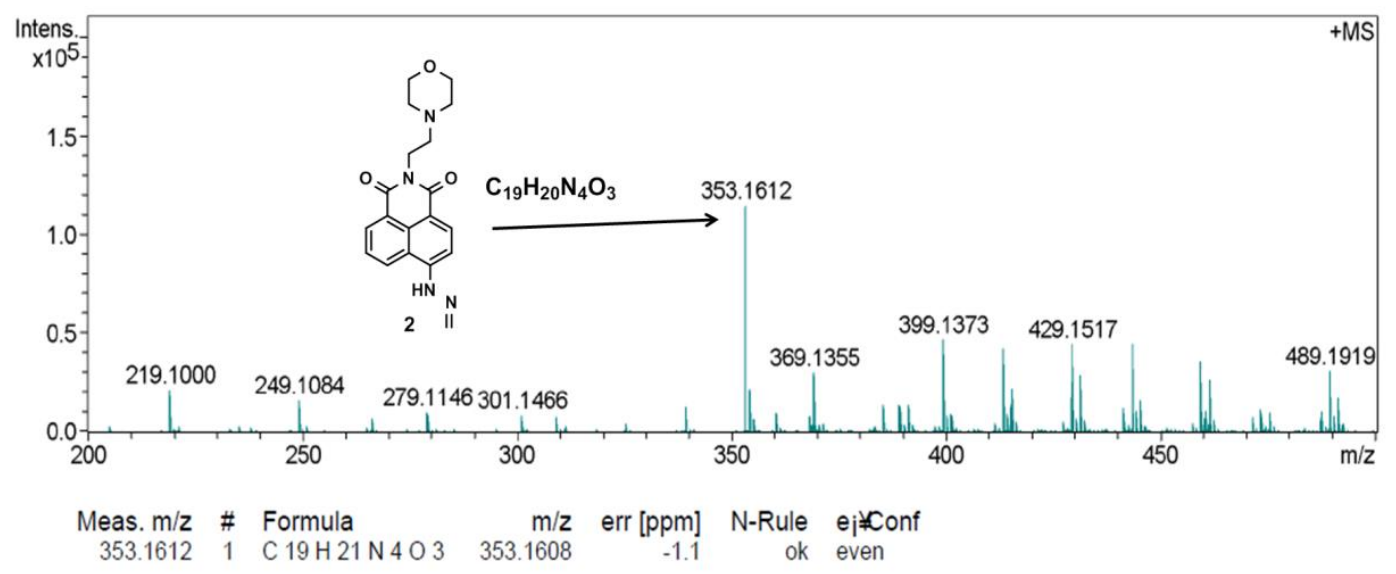

Figure S5. HR-MS spectrum of $50 \mu \mathrm{M}$ Na-FA-Lyso treated with $2 \mathrm{mM}$ FA in $10 \mathrm{mM}$ PBS buffer (pH 7.4, $1 \%$ DMSO).

Table S1. Some typical spectroscopic data for the reaction product (the compound 2) of the probe Na-FA-Lyso with FA.

\begin{tabular}{|c|c|c|c|}
\hline $\begin{array}{c}\text { Maximum } \\
\text { absorption } \\
\text { wavelength }(\lambda)\end{array}$ & $\begin{array}{c}\text { Molar absorption } \\
\text { coefficient }(\varepsilon)\end{array}$ & $\begin{array}{c}\text { maximum } \\
\text { emission } \\
\text { wavelength }(\lambda)\end{array}$ & $\begin{array}{c}\text { Fluorescence } \\
\text { quantum yield }(\Phi)\end{array}$ \\
\hline $440 \mathrm{~nm}$ & $20,800 \mathrm{M}^{-1} \mathrm{~cm}^{-1}$ & $543 \mathrm{~nm}$ & 0.31 \\
\hline
\end{tabular}


Kinetic studies: The rate constant was determined from the fluorescence titration data based on a reported method. ${ }^{2}$ The reaction of the probe Na-FA-Lyso $(5 \mu \mathrm{M})$ with FA in PBS (10 mM, pH 7.4, 1 \% DMSO) was monitored using the fluorescence intensity at $543 \mathrm{~nm}$. The reaction was carried out at room temperature. The pseudo-first-order rate constant for the reaction was determined by fitting the fluorescence intensities of the samples to the pseudo-first-order equation (3):

$$
\operatorname{Ln}\left[\left(\mathrm{F}_{\max }-\mathrm{F}_{t}\right) / \mathrm{F}_{\max }\right]=-\mathrm{k}^{\prime} t
$$

Where $\mathrm{F}_{t}$ and $\mathrm{F}_{\max }$ are the fluorescence intensities at $543 \mathrm{~nm}$ at time $t$ and the maximum value obtained after the reaction was complete. $\mathrm{k}$ ' is the pseudo-first order rate constant. The pseudo-first-order plots for the reaction of Na-FA-Lyso with 40 equiv. of FA is shown in Figure S6, The negative slope of the line provides the pseudo-first-order rate constant for FA.

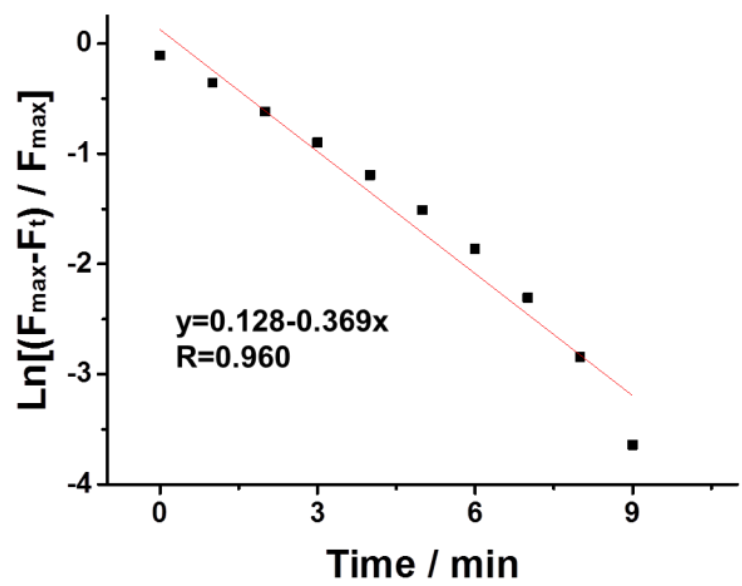

Figure S6. Pseudo-first-order kinetic plot of the reaction of Na-FA-Lyso $(5 \mu \mathrm{M})$ with FA (40 equiv.) in PBS (10 mM, pH 7.4, 1\% DMSO). Slope $=0.37 \mathrm{~min}^{-1}$.

${ }^{2}$ Dale T. J.; Rebek J. Jr. J. Am. Chem. Soc., 2006, 128, 4500-4501.

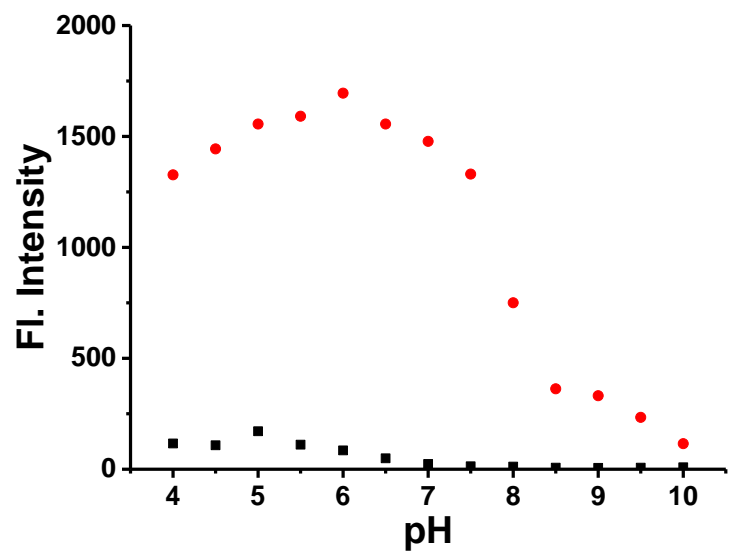

Figure S7. Fluorescence intensity changes of the probe Na-FA-Lyso $(5 \mu \mathrm{M})$ at different $\mathrm{pH}$ values in the absence $(\mathbf{})$ or presence $(\bullet)$ of FA (10 equiv.) for $30 \mathrm{~min}$. 


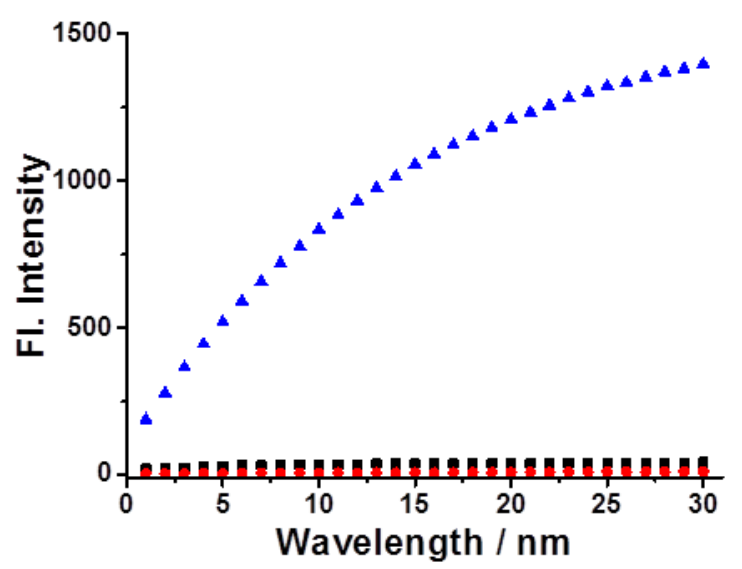

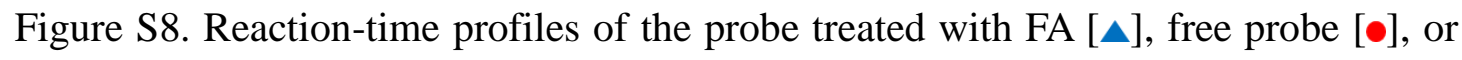
FA pre-incubated with $\mathrm{NaHSO}_{3}$ then treated with the probe [ $\mathbf{\square}$. The fluorescence intensities at $543 \mathrm{~nm}$ were continuously monitored at time intervals in PBS (10 mM, $\mathrm{pH} 7.4,1 \%$ DMSO). The concentrations for the probe, FA, and $\mathrm{NaHSO}_{3}$ are 5, 50, and $200 \mu \mathrm{M}$, respectively. $\lambda_{\mathrm{ex}}=440 \mathrm{~nm}$.

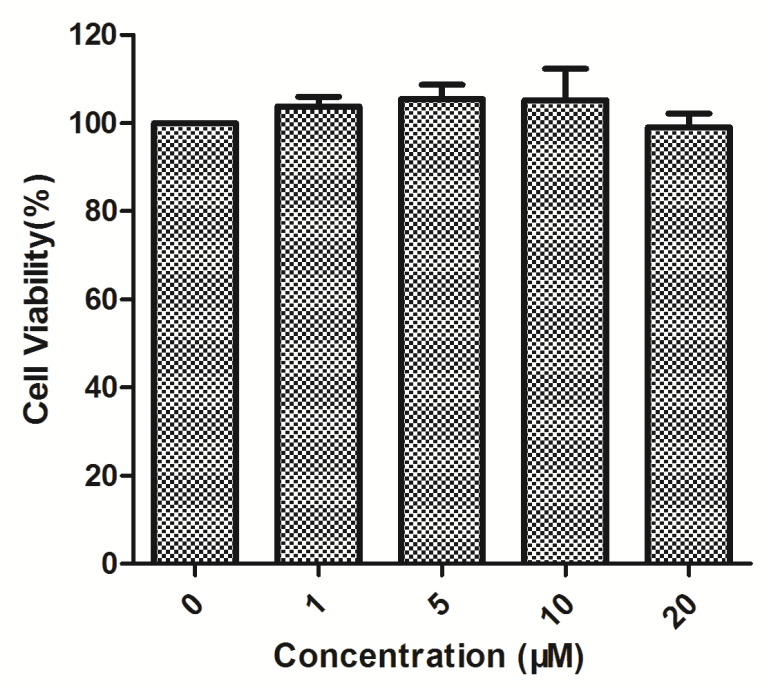

Figure S9. Effects of the probe Na-FA-Lyso with varied concentrations (0-20 $\mu \mathrm{M})$ on the viability of the Hela cells. The probe with varied concentrations was incubated with the cells for $24 \mathrm{~h}$. The viability of the cells in the absence of the probe is defined as $100 \%$, and the data are the mean standard deviation of five separate measurements. 


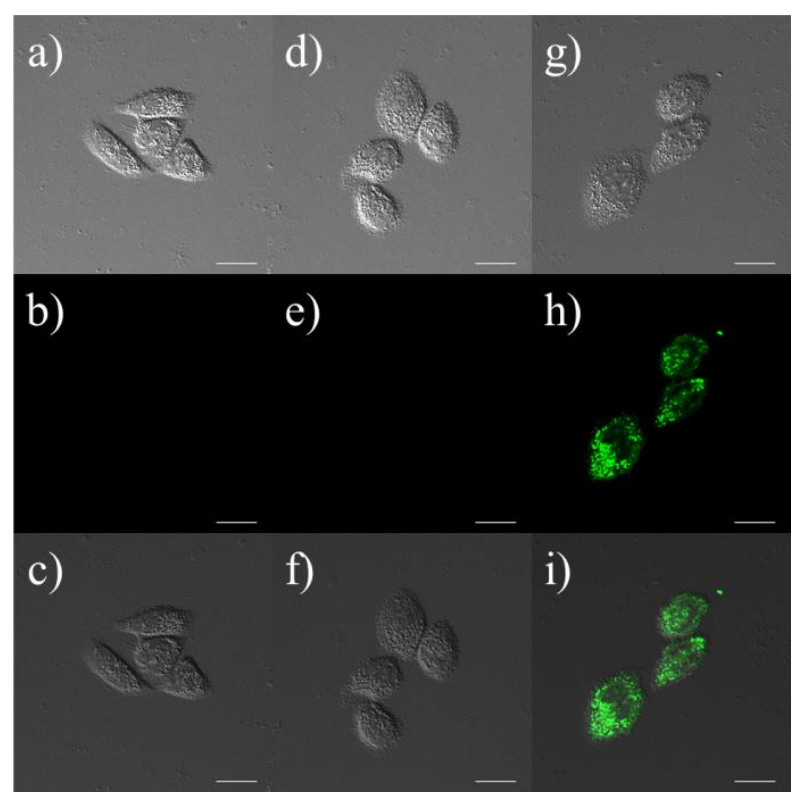

Figure S10. Fluorescence imaging of added FA in the living HeLa cells. a) Bright-field image of the living HeLa cells; b) The fluorescence image of a; c) The merge image of a and b); d) Bright-field image of the HeLa cells treated with FA (50 $\mu \mathrm{M})$; e) The fluorescence image of d; f) The merged image of $d$ and e; j) Bright-field image of the HeLa cells treated with Na-FA-Lyso $(5 \mu \mathrm{M})$ and FA $(50 \mu \mathrm{M})$; k) The fluorescence image of $j$; 1) The merged image of $j$ and $k$. Excitation was at $488 \mathrm{~nm}$ and emission collection was from $500-550 \mathrm{~nm}$. Scale bar: $20 \mu \mathrm{m}$.

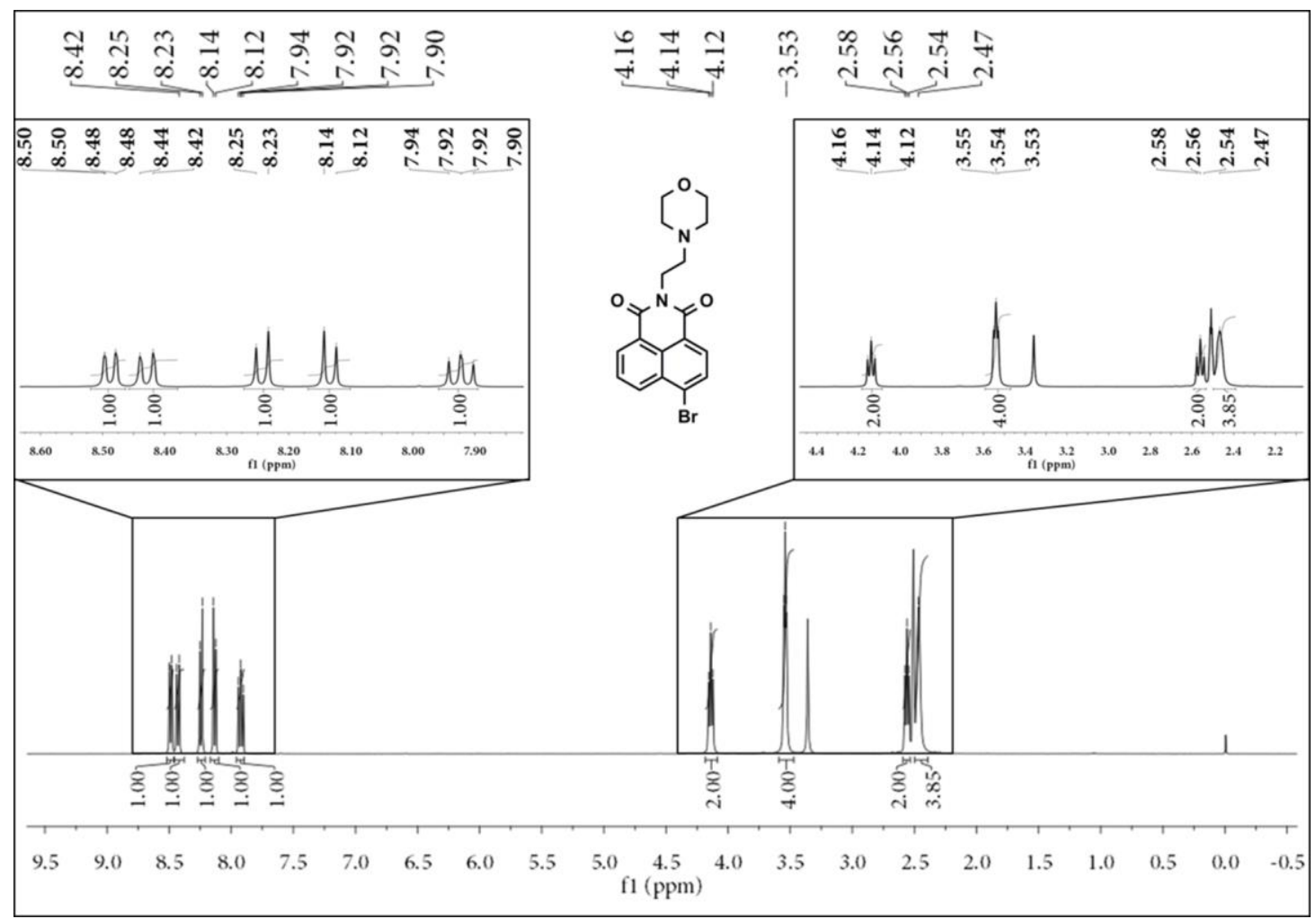

Figure S11. ${ }^{1} \mathrm{H}$ NMR spectrum of the compound $\mathbf{1}$. 


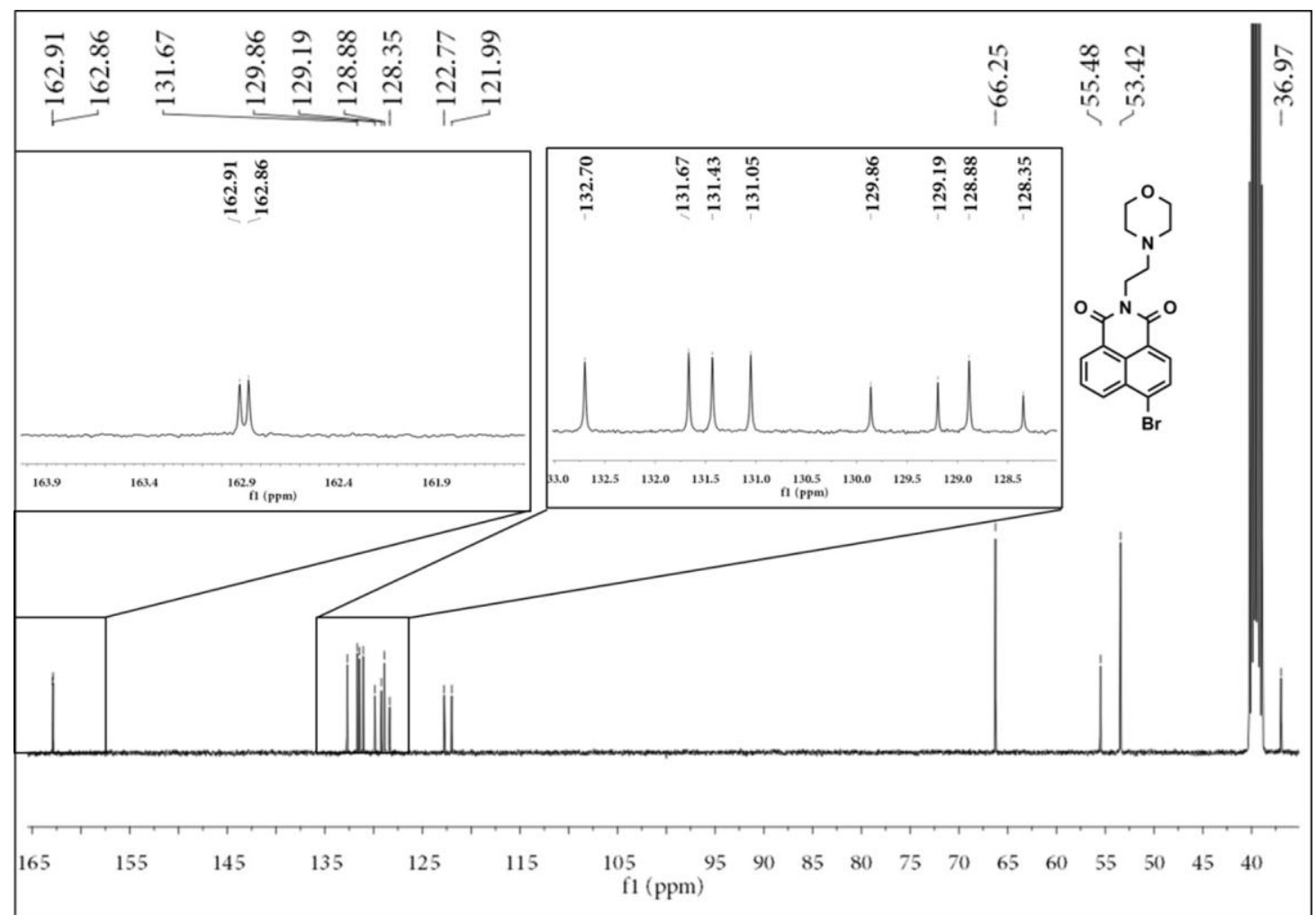

Figure S12. ${ }^{13} \mathrm{C}$ NMR spectrum of the compound $\mathbf{1}$.

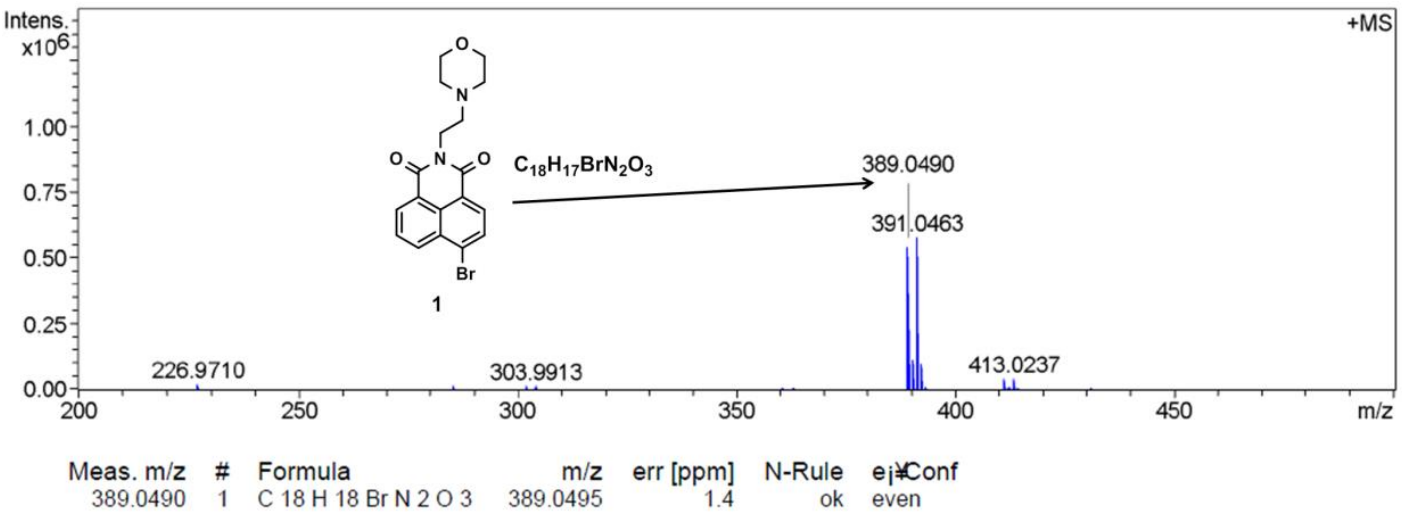

Figure S13. HR-MS spectrum of the compound 1. 


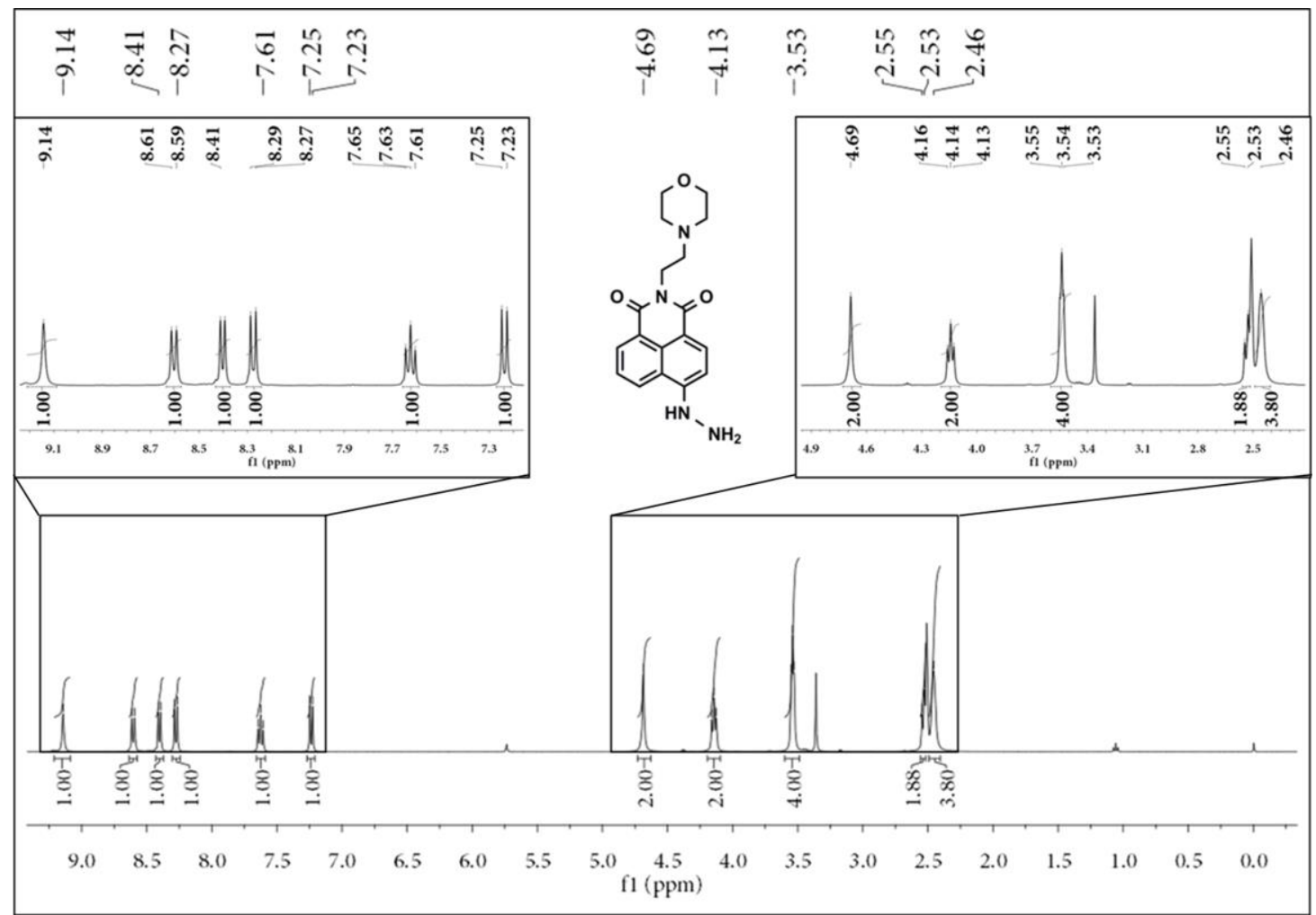

Figure S14. ${ }^{1}$ H NMR spectrum of the probe Na-FA-Lyso.

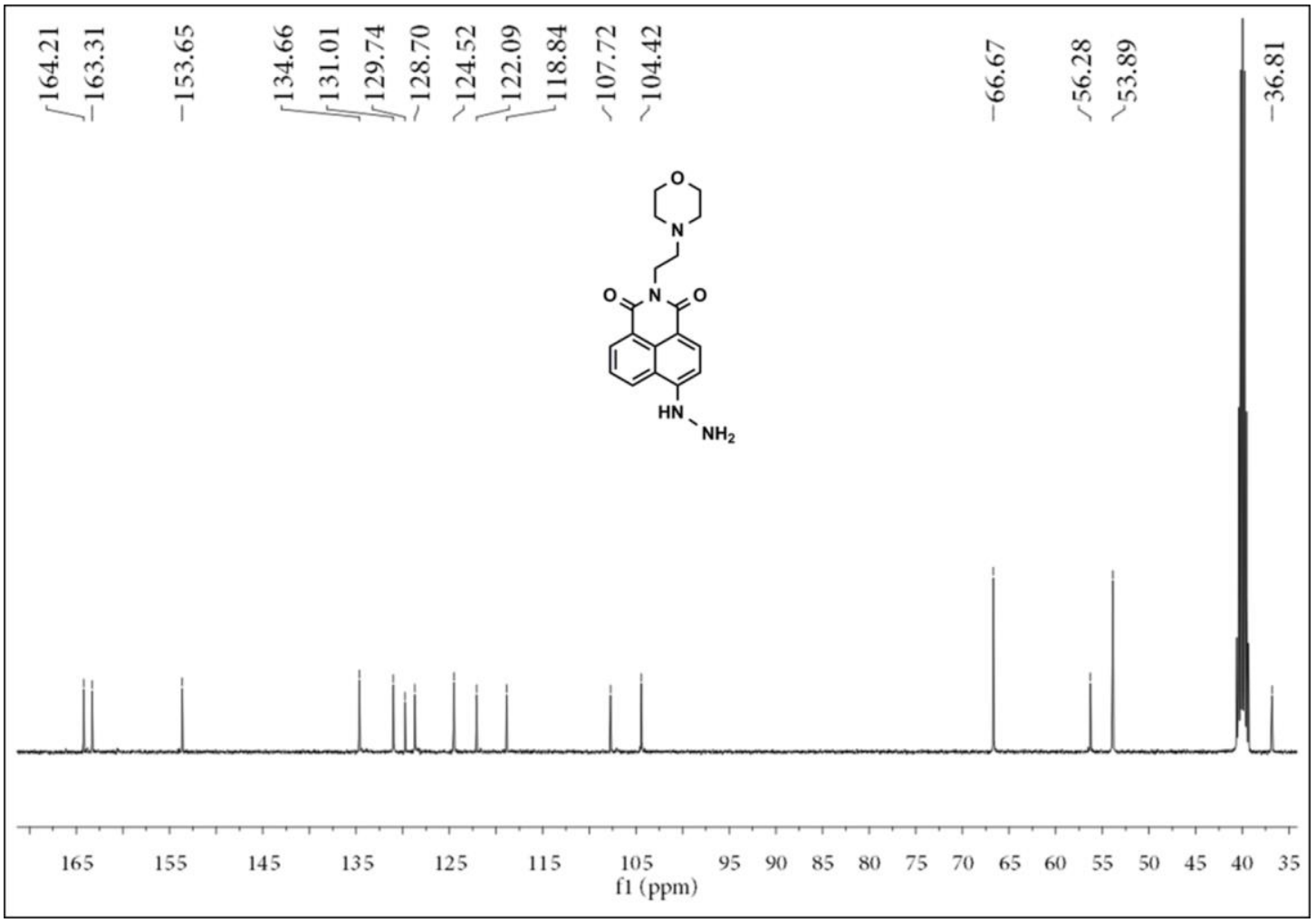

Figure S15. ${ }^{13}$ C NMR spectrum of the probe Na-FA-Lyso. 


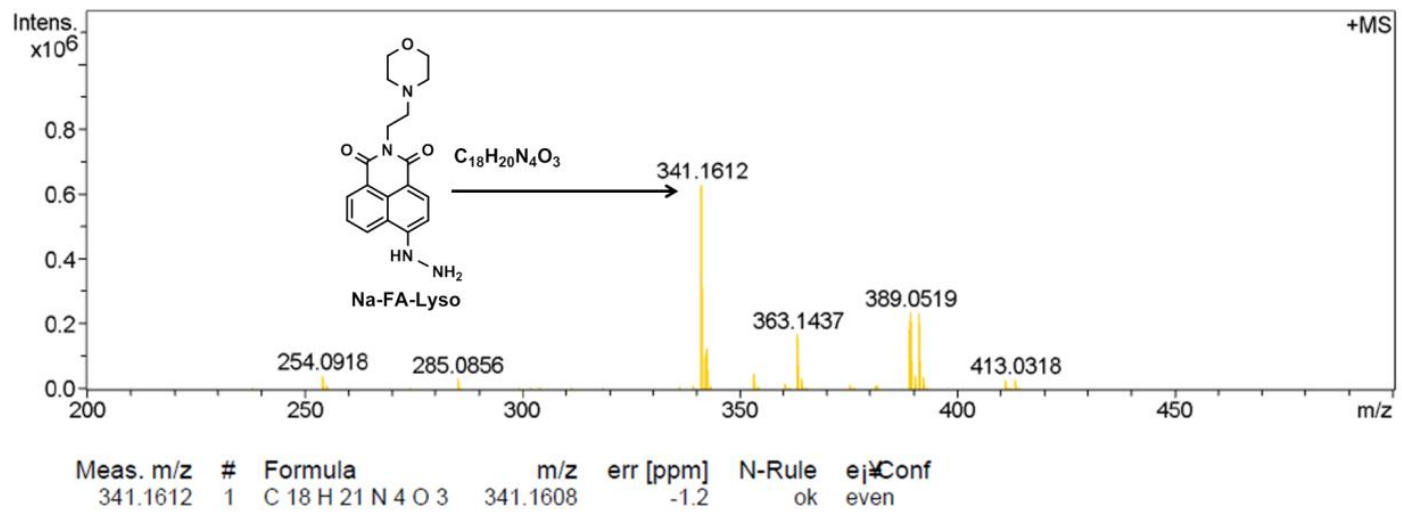

Figure S16. HR-MS spectrum of the probe Na-FA-Lyso. 